\title{
Will the unemployment rate fall with a robust forecast for the U.S. current account balance?
}

\author{
Mehdi Hojjat a* \\ a Professor, Neumann University, Aston, PA, USA \\ ${ }^{*}$ Corresponding author's e-mail: hojjatm@neumann.edu
}

H I G H L I G H T S:

1. The U.S. current account improvement generates higher level of employment. There two are statistically correlated.

2. The employment created by the improvement in the current account is mostly in the export sector.

3. More higher-paying jobs can be created if the U.S. provides incentive for manufacturers to use local contents in their products.

4. Regional trade agreements neither help U.S. current account balance nor its employment.

\begin{tabular}{ll}
\hline Article History & ABSTRACT \\
\hline Received:10-08-2014 & This paper investigates the relationship between the U.S. current account balance and the \\
Revised receipt: $23-08-2014$ & $\begin{array}{l}\text { U.S. rate of unemployment. Would the improvement in the current account balance cause a } \\
\text { fall in the unemployment rate? Although previous researchers argued that U.S. current } \\
\text { Accepted: } 28-08-2014\end{array}$ \\
$\begin{array}{l}\text { account balance does not influence U.S. unemployment rate, this article shows that these } \\
\text { two are statistically correlated. This article also suggests policy recommendations that } \\
\text { benefit both the employment level and the U.S. current account balance. }\end{array}$
\end{tabular}

Balance of payment;

Current account balance:

US trade deficit.

JEL Classification:

E43; J31.

DOI: http://dx.doi.org/10.18533/jefs.v2i03.88

(C) 2014 The Authors. This is an open access article under the terms of the Creative Commons Attribution License 4.0, which allows use, distribution and reproduction in any medium, provided the original work is properly cited.

\subsection{Introduction}

The current account balance consists of four categories: balance on goods trade, balance on service, balance on income receipts and payment, and unilateral trade balance. On a theoretical basis, when a country reports a current account surplus or an improvement in the current account, it is an indicative of more exports or more income receipts compared to imports and payments to foreigners. More exports mean more jobs and almost certainly higher paying jobs in manufacturing and production sectors. Therefore, improvement in the balance of payment is always good news for the main street. It is good for you, your neighbor, your town and your country. It is a sign of strengthening of the U.S. international competitiveness, therefore, it is the reason that you should care about the status of the U.S. current account balance.

One of the most volatile economic consequences of the global financial crisis was a decline in the U.S. trade deficit in 2009 and subsequent improvement in the U.S. current account balance. After 2009, creation of new natural gas industry not only significantly reduced the U.S. import of energy products but also created thousands well-paying jobs in this industry. 
At the same time, rising demand for U.S. exports to emerging markets such as the BRICK countries (Brazil, Russia, India, China and Korea) means higher demand for the U.S. dollar which maintains its value as the most important reserve currency in the world. This article examines recent data on the U.S. current account to see it diverges from the old declining pattern. The article, using the forecasted trend in the U.S. current account balance, shows its impact on the U.S. unemployment rate.

\section{$2.0 \quad$ Literature review}

In 1998, Daniel Griswold from the Cato Institute ${ }^{1}$ wrote an article about the U.S. trade deficit. He wrote that article two years after the 1996 Asian financial turmoil. As he was projecting a deeper and deeper deficit for the U.S. current account balance, one of the main points of the article was the following: the U.S. trade deficit has no relationship with the U.S. unemployment rate. This point is still valid. In recent years, inflection points appear in all trade data that make many of the previous trade analysis erroneous.

In 2014, five years after the global financial crisis, this article broadens Griswold's research from a mere trade balance to the U.S. current account balance and comes up with a very different conclusion. Let us first examine the most recent data and present an analysis of the current account. In 2007, Doug Karmin (2007) asserted that the U.S. trade deficit was one of the largest deficits in the U.S. history. He projected that $\$ 800$ billion deficit in 2007 was more than $6 \%$ of the U.S. Gross National Income. At that time, there were legitimate reasons to be concerned about the economic impact of such enormous trade imbalances. Despite the litany of reports and assumptions to the contrary, however, the threat of rampant job loss is not one of them. However, Karmin (2007) mistakenly concludes that there was no proven link between trade deficits and rising unemployment ${ }^{2}$

Another research, James Moreland (2014), recently stated that the U.S. trade policy basically induce firms to take their productions to other countries and do not penalize them for exporting the same product back to the U.S. consumers. This policy which is continuing has cost U.S. millions of good paying manufacturing jobs. The U.S. Department of Commerce estimates that for 5000 jobs are created for every billion dollar exported goods. The reality is that this calculation works both ways and for every billion dollar replacement imports, 9000 jobs are destroyed, according to the data from the Economic Policy Institute shows. ${ }^{3}$ According to Moreland, "Free" trade has not been free at all, but has cost America millions of jobs. Unfortunately Moreland does not provide any statistical analysis to prove his point.

Jonathan Eaton, Samuel Kortum and Brent Neimann (2013) studied unemployment rate in Europe between 2007 and 2011. In this period, this rate increased substantially during the same period that a number of European countries experienced large decline in their trade deficits. The three researchers use a general equilibrium, thirtyfour country Ricardian model with potential wage inflexibility to explore the relationships among external adjustment, relative GDP, and unemployment over the period. Their analysis provides decomposition between how increased unemployment and relative wage declines bore the burden of adjustment to lower external deficit. 4

Houseman (2014) focuses her attention on globalization's effects on workers. While many are concerned that the rapid growth of trade has harmed job growth in the United States, the Great Recession and weak jobs recovery since 2009 has encourage the U.S. Administration to turn into export promotion policies to increase exports to boost employment. The indirect foreign labor contents of U.S. manufactured goods has risen substantially since the mid1990s, underscoring the importance of accounting for imported intermediates in estimating the domestic employment effects of export promotion policies. ${ }^{5}$ It appears that proving incentives for manufacturing firms to use domestic contents, as the expenses of foreign contents, can be an effective tool in generating employment. Given that the export sector of the economy is 12 percent of GDP and the manufacturing sector is several times that size, this tool can be a more potent in lowing employment rate than export promotion policies.

Yuan (2014) examined the U.S. trade deficit with China and concluded that the U.S. trade deficit with has little to do with trade in China and the U.S. unemployment rate. This is hard to believe because U.S. is the largest trade partner and over-sea market of China and China is the largest trade deficit source of the U.S. In 2013, the deficit with China constitutes forty three percent of total U.S. trade deficit. 6 United States blames this deficit on China's exports and

\footnotetext{
${ }^{1}$ Griswold, Daniel, T. (1998), America's Maligned and Misunderstood Trade Deficit. Retrieved from www.ciaonet.org

2 Karmin, Douglas. (2007). "The Facts on Trade", Progressive Policy Institute. Retrieved from http://www.dlc.org/documents/TradeJobs100107.pdf

${ }^{3}$ Moreland, James. (2014). “U.S. Trade Deficit Fosters Unemployment”, American Economy Report, February 2, 2014.

${ }^{4}$ Eaton, J, Kortum, S and Neimann, B. (2013). "On Deficit and unemployment". Based on Eaton's keynote address at the meeting of Association Francaise de Science Economique on July 3, 2012.

5 Houseman, Susan (2014). "Trade, Competitiveness and Employment in the Global Economy”, Employment Research Newsletter, Upjohn Institute, Volume 21, Number 1, 2014.

${ }^{6}$ Hojjat, Mehdi (2014). “Do Multinational Trade Agreements Help or Hinder Improvement in the U.S. Current Account Balance?” , Global Journal of Business Research, Volume 8, Number 4, September 2014.
} 
exchange rate of RMB, and tries to contribute them to the U.S. unemployment rate. Yuan states that even when there are no China's exports the U.S. trade deficit will not disappear. The U.S. trade deficit with China is an excuse, which the U.S. takes to suppress China's economic advantage. ${ }^{7}$

These points are valid but less important since in recent years we are observing inflection points in all trade data that make much of the previous trade analysis erroneous. In this article, I am expanding the scope of previous researches by connecting the unemployment rate not just to trade deficit but to a broader measure of U.S. external trade which is the U.S. current account. Furthermore, this research uses the latest forecast in the U.S. current account balance that shown an inflection point missed in previous researches.

\subsection{Data and methodology}

In July 2014, the U.S. Department of Commerce reported that the U.S. trade deficit narrowed as exports reached to a yet another record high, and at the same time, the U.S. unemployment rate dropped to its lowest level in six years. ${ }^{8}$ In this report, the Commerce Department_stated that the trade deficit declined 5.6 percent to $\$ 44.4$ billion. The recent improvement in U.S. exports suggests a much brighter outlook for the employment picture in the U.S., as more export creates more jobs. The U.S. current-account deficit; which is a combined balance on trade in goods and services, income, and net unilateral current transfers, declined to $\$ 98.9$ billion in the second quarter of 2013 from $\$ 104.9$ billion in the first quarter of 2013 . The decrease in the current account deficit was accounted for by a decline in the deficit on imported goods, a rise in the surplus on income, and a surge in the surplus on services.

\subsection{Projection of the current account balance}

Throughout the 1980s and 1990s, the current account deficit created worry about "unfair" foreign trade practices, loss of U.S. jobs, and the U.S. ability to compete in the global marketplace. However, the argument of this section will show that none of these statements is true. In early 1990s, annual U.S. trade deficits reached unprecedented levels. After three decades of surpluses, the U.S. current account deficit reached a record of $\$ 800$ billion in 2007, as a percentage of GDP; it approached the unprecedented level of $6 \%$ (see Figure 2). In the aftermath of the global financial crisis, the current account deficit started to shrink. By 2009, the account trade deficit was cut in half to less than $\$ 400$ billion, which shattered all doom and gloom projections in this area.

In 2014, five years after the global financial crisis, I broaden previous researches from just a trade balance to the U.S. current account balance and examine the most recent data and analyze the current account in a relationship to the recent unemployment rates.

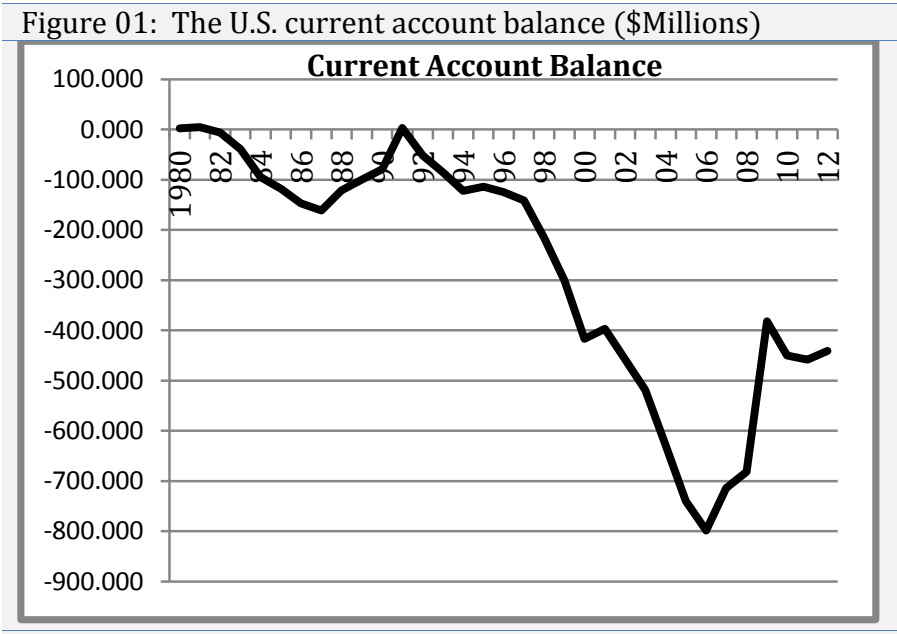

Figure 1 shows quarterly data of the U.S. current account balance from 1980 through 2013. The inflection point took place in the last quarter of 2006 and the improvement is continuing.

Source of Data:

U.S. Bureau of Census and Federal Reserve Economic Data. Retrieved from http://research.stlouisfed.org/fred2
Figure 02: The U.S. current account balance as percentage of GDP

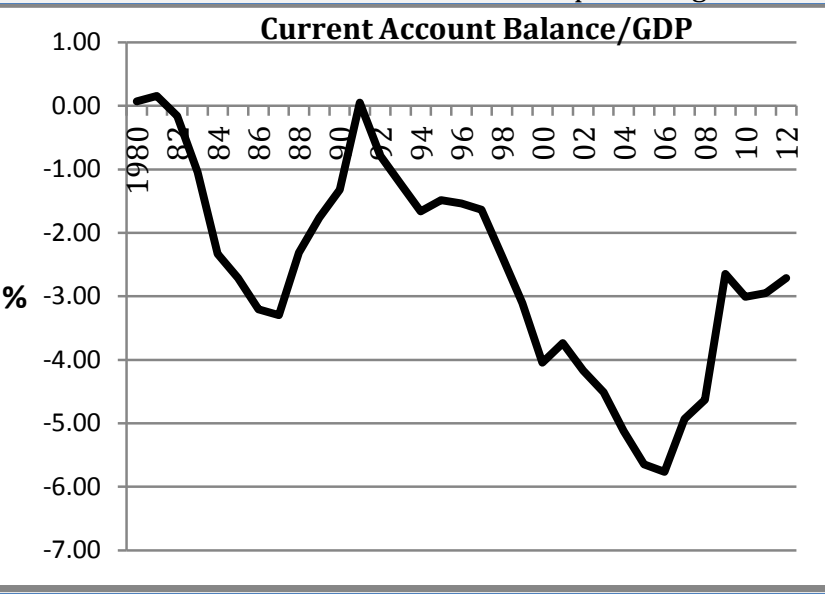

Figure 2 shown the U.S. current account balance as a percentage of U.S.GDP. Again inflection point happens in 2006 and the improvement is continuing. Source of Data:

U.S. Bureau of Census and Federal Reserve Bank of St. Louis. Retrieved from http://research.stlouisfed.org/fred2

\section{Figure 3 - Projected U.S. current account balance (\$b)}

\footnotetext{
${ }^{7}$ Yuan, Tao (2014) “The U.S. Trade Deficit with China: An Excuse”, On China's Trade Surplus, pp77-94

${ }^{8}$ VOA News, "US Trade Deficit Narrows as Exports Hit Record High", July 3, 2014.
} 


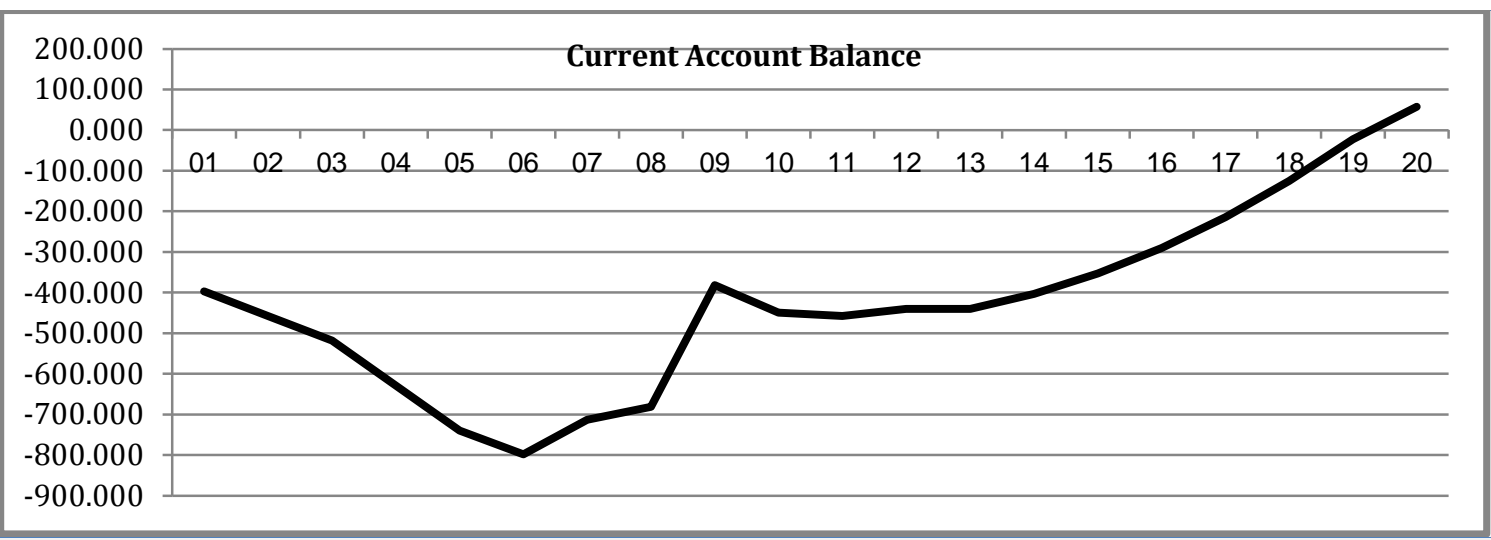

Figure 3 is the projection of the U.S. current account balance based on cross-sectional analysis of trade and service accounts of the U.S. balance of payments account. The assumptions include 4 percent increase in the service account, four percent decline on petroleum imports and a gradual increase in LNG exports from Louisiana and Maryland LNG ports. For more information see Hojjat (2014): "Cross-Sectional and Time Series Forecast of the U.S. Current Account Balance

Hojjat (2014) demonstrated that the U.S. Current Account balance will reach equilibrium by $2020 .{ }^{9}$ Figure 3 demonstrates this projection which is based on the following three assumptions: (1) Four percent improvement of trade in services per year, (2) Increase in export of LNG from 1 billion cubic feet (CF) in 2014 to 6 billion CF by 2020, and (3) reduction of 4 percent in imports of petroleum products, including crude oil. Hojjat confirmed this cross-sectional projection by also conducting a time series forecast.

Table 01 is the numerical presentation of the above graph, showing a positive balance by 2020. Both time series and cross section projections display a rather robust outlook for the U.S. current account balances. Both are projecting that by 2020 the U.S. will have a current account surplus.

Since the focus of this research is to show the relationship between the U.S. current account and employment, readers can review the projection in the above referenced citation.

\begin{tabular}{|c|c|}
\hline \multicolumn{2}{|c|}{ Table 01: Projected U.S. current account balance $(\$ b)$} \\
\hline 2014 & -193.22 \\
\hline 2015 & -149.36 \\
\hline 2016 & -105.5 \\
\hline 2017 & -61.64 \\
\hline 2018 & -17.78 \\
\hline 2019 & 26.08 \\
\hline 2020 & 69.94 \\
\hline \multicolumn{2}{|c|}{$\begin{array}{l}\text { Table } 1 \text { presents the projection of the U.S. current account balance, equilibrium will be achieved by } \\
2018 \text { and for the first time in } 4 \text { decades U.S. will have a surplus in the current account balance by } \\
2020 \text {. }\end{array}$} \\
\hline
\end{tabular}

\subsection{U.S. unemployment rate and current account}

There is a debate among economists about the effect of higher trade and current account deficits on the rate of unemployment. Some blame globalization and outsourcing as the main reasons for both a higher rate of employment and the trade deficit. The relationship seems to be obvious: more outsourcing results in loss of jobs and more imports results a higher trade deficit. A 1997 study by the Institute for Policy Studies asserted that a large trade deficit caused by the East Asian financial meltdown cost the U.S. economy more than 1 million jobs. ${ }^{10}$ The U.S. Department Commerce estimates that for every $\$ 1$ billion of exports, 20,000 jobs are created. That's 3.5 million American workers who would have good manufacturing jobs if U.S. simply closes its trade imbalance.

On the other hand, Griswold (1998) ${ }^{11}$ believes that all these estimates are based on a basic misunderstanding between the relationship of trade deficit and employment rate. He stated that the total number of jobs in the United States is largely determined by fundamentally macroeconomic factors such as labor-supply growth and monetary

\footnotetext{
${ }^{9}$ Hojjat, M. (2014), "Cross sectional and Time Series Forecast of the U.S. Current Account Balance”, Journal of International Business and Economics, American Research Institute for Policy Development (www.aripd.org/jibe).

${ }^{10}$ Quoted in Wayne Leighton, "Playing with the Numbers: Why Protectionists Are Wrong about Trade," Issue Analysis, Citizens for a Sound Economy Foundation, Washington, September 18, 1997, p. 1. Buchanan made his remark on CNN on March 3, 1996.

${ }^{11}$ Griswold, Daniel, T. (1998), America's Maligned and Misunderstood Trade Deficit.
} 
policy, therefore, trade with other nations does not affect the number of jobs created or lost in the United States. Trade lowers demand for jobs in one sector and increases demand for jobs in other sectors. For example, trade allows the United States to export more Boeing jetliners, pharmaceuticals, software, and financial services for export creating more jobs in these sectors. And at the same time, trade may mean that U.S. produces fewer shoes and t-shirts, hence, losing jobs in these sectors. Meanwhile, total output and employment keep growing.

He showed that larger trade deficits can correlate positively with falling unemployment. Using recent data on the current account, the above hypothesis can be tested. A linear regression was run on the data: unemployment rate as a dependent variable and current account deficit as percentage of GDP as an independent variable. Here is the regression equation between these two variables:

$$
\begin{array}{lr}
\mathrm{Y}=12.38+ & 1.366 \mathrm{X} \\
\mathrm{t}-\text { statistics } & (14.3) \\
\mathrm{R}^{2} & 0.8313
\end{array}
$$

Where Y presents the U.S. unemployment rate and X presents the U.S. current account deficit as percentage of GDP, t-statistics is 14.3 which provide $98 \%$ confidence interval. $\mathrm{R}^{2}$ is .8313 , it represents the goodness of fit which means that 83.13 percentage of variations in $\mathrm{Y}$ can be explained by independent variable, $\mathrm{X}$. The following table presents the full regression results between these two variables.

Regression results show a significant relationship between these two variables, as the U.S. current account

\begin{tabular}{|c|c|c|c|c|c|}
\hline \multicolumn{2}{|c|}{$\mathrm{Y}=$ Current Account Deficit as \% of GDP } & \multicolumn{4}{|c|}{$\mathrm{X}=$ Unemployment Rate } \\
\hline Multiple R & 0.911797007 & & & & \\
\hline R Square & 0.831373782 & & & & \\
\hline Adjusted R Square & 0.812637536 & & & & \\
\hline Standard Error & 0.830419211 & & & & \\
\hline \multirow[t]{2}{*}{ Observations } & 11 & & & & \\
\hline & $\mathrm{df}$ & SS & MS & $\mathrm{F}$ & Significance $\mathrm{F}$ \\
\hline Regression & 1 & 30.59908995 & 30.59909 & 44.37248 & $9.25379 \mathrm{E}-05$ \\
\hline Residual & 9 & 6.206364594 & 0.689596 & & \\
\hline \multirow[t]{2}{*}{ Total } & 10 & 36.80545455 & & & \\
\hline & Coefficients & Stand. Error & t Stat & P-value & Lower 95\% \\
\hline Intercept & 12.38330898 & 0.865624021 & 14.30564 & $1.7 \mathrm{E}-07$ & 10.4251314 \\
\hline X Variable 1 & 1.366940458 & 0.205207264 & 6.661267 & $9.25 \mathrm{E}-05$ & 0.902729376 \\
\hline
\end{tabular}
improves, its unemployment rate falls. Figure 4 illustrates how closely the unemployment rate corresponds with changes in the current account deficit. ${ }^{12} \backslash$

Figure 04: Current account as \% of GDP (Left) and Figure 05: Correlation between current account deficit/GDP unemployment rate (right scale)

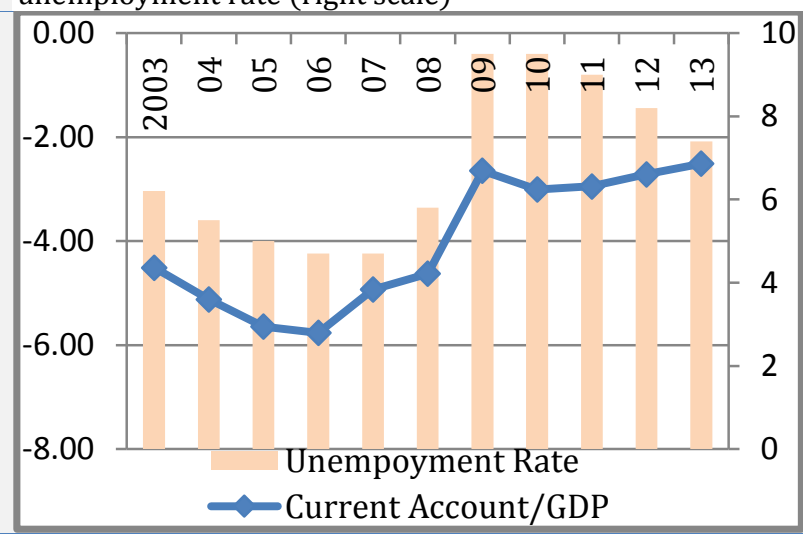
and unemployment rate

\footnotetext{
${ }^{12}$ Source of data: Bureau of Labor Statistics (unemployment rate for the year is represented by the rate in July of that year) and Bureau of Economic Analysis (current account deficit as a percentage of GDP for 2013 is estimated)
} 
The current account deficit is now shrinking, and the unemployment rate is falling. As the deficit shrank during the period of 2009-2013, the unemployment rate steadily declined. But the unemployment also declined when the deficit expanded in the 2003-2006 period. As the trade deficit declined in the 2007-2009 period, the unemployment rate rose. Overall, there seems to be very little relationship between the current account deficit and the unemployment rate. However, in recent years, improvement in the unemployment rate is positively associated with an improvement in the current account balance.

\subsection{Conclusion and policy implications}

Recent current account data indicates that U.S. is nearing an inflection point in the projection of its current account deficit. This article estimated that by 2020, the U.S. will post current account surpluses, thanks mostly to the improvement in the U.S. trade balance. Higher exports, especially the export of energy products and lower imports of energy will make this happen. The current account will also receive a boost from higher surpluses in the service and income accounts. The article also showed that unlike many previous projections, there is a positive relationship between improvement in the current account balance and improvement in the unemployment rate, although using quarterly data might make this relationship more statistically significant.

Some of the policy implications from this article include the following: (a) export promotion policies should be continued with more vigor to encourage small and medium size firm start exporting, (b) policies should be developed to encourage the use of local content in manufactured goods, such as using steel poured in the U.S. for infrastructure projects, (c) regional trade agreement does not help the U.S. current account, hence they do not help employment, therefore, policy makers should not pursue them, and (d) the U..S trade policy should be focused on reducing trade barriers by discussing them at the World trade Organization (WTO), rather than by taking unilateral and bilateral actions. It provides a better trade outlook for U.S. when the world is open for business rather than country or a region.

\section{References}

Eaton, J, Kortum, S and Neimann, B. 2013. On deficit and unemployment. Based on Eaton's keynote address at the meeting of Association Francaise de Science Economique on July 3, 2012. Retrieved from http://faculty.chicagobooth.edu/brent.neiman/research/EKN.pdf

Griswold, Daniel, T. 1998. America's maligned and misunderstood trade deficit. Retrieved from www.ciaonet.org

Hojjat, Mehdi. 2014. Cross-sectional and time series forecast of the U.S. current account balance. Journal of International Business and Economics, American Research Institute for Policy Development (www.aripd.org/jibe).

Hojjat, Mehdi. 2014. Do multinational trade agreements help or hinder improvement in the U.S. current account balance?, Global Journal of Business Research , Volume 8, Number 4. September 2014.

Houseman, Susan. 2014. Trade, competitiveness and employment in the global economy, Employment Research Newsletter, Upjohn Institute, Volume 21, Number 1, 2014. Retrieved from http://research.upjohn.org/cgi/viewcontent.cgi?article=1216\&context=empl_research\&seiredir=1\&referer =http\%3A\%2F\%2Fscholar.google.com.ezproxy.neumann.edu\%2Fscholar\%3Fas_ylo\%3D20

Karmin, Douglas. 2007. The facts on trade. Progressive Policy Institute. Retrieved from http://www.dlc.org/documents/TradeJobs100107.pdf

Moreland, James. 2014. U.S. trade deficit fosters unemployment. American Economy Report, February $2,2014$. Retrieved from http://economyincrisis.org/content/lack-jobs-due-our-massive-trade-deficit

Nir, J and Taylor L. 2013, Economic growth in foreign regions and U.S. export growth. Economic Review, Federal Reserve Bank of Kansas City.

VOA News, US trade deficit narrows as exports hit record high, July 3, 2014. Retrieved from http://www.voanews.com/content/reu-trade-deficit-narrows-as-export-hit-record-high/1949981.html

Yuan, Tao, 2014. The U.S. trade deficit with china: an excuse. On China's Trade Surplus, pp77-94 